J. Clin. Chem. Clin. Biochem.

Vol. 21, 1983, pp. 503-509

\title{
Selective Determination of the Activities of Neutral and Acid $\alpha$-Glucosidase Using Discontinuous Assays
}

\author{
By Gabriela Kochmann, R. Kochmann, W. Pape, M. Blank and K. Baumann \\ Abteilung für Zellphysiologie, Physiologisches Institut der Universität Hamburg
}

(Received September 1, 1981/April 18, 1983)

Summary: Most biological fluids contain both neutral and acid $\alpha$-glucosidase. Optimal conditions were therefore developed for the selective determination of the activity of neutral and acid $\alpha$-glucosidase, using 2 -step, discontinuous assays. In the first step of the assay of neutral $\alpha$-glucosidase, glucose was liberated from maltose (citrate-phosphate buffer, $\mathrm{pH} 6.8,20 \mathrm{mmol} / \mathrm{l}$ maltose, $25 \mathrm{mmol} / \mathrm{l}$ turanose). Under these incubation conditions, turanose inhibited the residual activity of acid $\alpha$-glucosidase almost completely without influencing the activity of neutral $\alpha$-glucosidase. In the first step of the acid $\alpha$-glucosidase assay, glucose was liberated from maltose (citrate-phosphate buffer, $\mathrm{pH} 3.8,50 \mathrm{mmol} / 1$ maltose, $2 \mathrm{~mol} / 1$ potassium chloride). Under these incubation conditions, potassium ions stimulate the activity of acid $\alpha$-glucosidase and simultaneously inhibit almost completely the residual activity of neutral $\alpha$-glucosidase. In the second step of the assay of neutral and acid $\alpha$-glucosidase, the liberated glucose was measured by hexokinase/glucose- 6 -phosphate dehydrogenase. The effect of turanose and potassium ions on neutral and acid $\alpha$-glucosidase from human urine was characterized.

\section{Selektive Bestimmung der Aktivität von neutraler und saurer $\alpha$-Glucosidase in diskontinuierlichen Tests}

Zusammenfassung: Die meisten biologischen Flüssigkeiten enthalten gleichzeitig Aktivitäten von neutraler und saurer $\alpha$-Glucosidase. Es wurden optimale Bedingungen für diskontinuierliche Tests in zwei Schritten zur selektiven Aktivitätsbestimmung von neutraler und saurer $\alpha$-Glucosidase entwickelt. Im ersten Schritt der Bestimmung der neutralen $\alpha$-Glucosidase wird Glucose aus Maltose freigesetzt (Citrat-Phosphat-Puffer, $\mathrm{pH} 6,8,20 \mathrm{mmol} / 1$ Maltose, $25 \mathrm{mmol} / 1$ Turanose). Bei den gewählten Inkubationsbedingungen hemmt Turanose die verbleibende Aktivität von saurẹ $\alpha$-Glucosidase fast vollständig, ohne die Aktivität der neutralen $\alpha$ Glucosidase zu beeinflussen. Im ersten Schritt der Bestimmung der sauren $\alpha$-Glucosidase wird Glucose aus

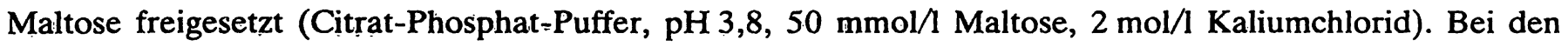
gewählten Inkubationsbedingungen stimulieren Kaliumionen die Aktivität der sauren $\alpha$-Glucosidase bei gleichzeitiger fast vollständiger Hemmung der verbleibenden Aktivität von neutraler $\alpha$-Glucosidase. Im zweiten Schritt der Bestimmung der neutralen und sauren $\alpha$-Glucosidase wird die freigesetzte Glucose mit der Hexokinasemethode gemessen. Der Effekt von Turanose und Kaliumionen auf die neutrale und saure $\alpha$ Glucosidase aus menschlichem Urin wurde charakterisiert.

\section{Introduction}

$\alpha$-Glucosidase activity has been measured either photometrically by using maltose as substrate or by a fluorescent assay with synthetic 4-methyl-umbelliferyl- $\alpha-D$-glucopyranoside as substrate (1). The glucose liberated from maltose was assayed with $o$-toluidine (2), or enzymatically by glucose oxidase (3) or hexokinase/glucose-6-phosphate dehydrogenase (4). Determinations were performed at optimal pHvalues for neutral $\alpha$-glucosidase (around $\mathrm{pH} \mathrm{7.0)}$ ) as well as for acid $\alpha$-glucosidase (around $\mathrm{pH} 4.0$ ). But due to their broad $\mathrm{pH}$-optima neutral $\alpha$-glucosidase (EC 3.2.1.20, $\alpha$-D-glucoside glucohydrolase) revealed considerable enzymatic activity under acidic 
conditions at $\mathrm{pH} 4.0(5,6)$, whereas acid $\alpha$-glucosidase (EC 3.2.1.3, 1,4- $\alpha$ - $D$-glucan glucohydrolase) revealed moderate activity at $\mathrm{pH} 7.0(6,7,8)$. Thus by using optimal $\mathrm{pH}$-values only it was impossible to differentiate between both enzymatic activities. Potassium ions have already been used to improve the selectivity of the determination of the acid $\alpha$-glucosidase (6).

Since most biological fluids contain various amounts of both neutral and acid $\alpha$-glucosidase, the purpose of the present investigation was to study the kinetic properties of both enzymes to develop optimal test conditions for their selective determination. Both $\alpha$ glucosidases were separated and partially purified from human urine, and their enzymatic properties relating to turanose and to potassium ions were characterized. The subsequent paper (9) presents the differentiated urinary excretion of neutral as well as acid $\alpha$-glucosidase activity in control subjects.

\section{Materials and Methods}

Reagents

Bovine serum albumin (99\%), Triton X-100 and $D(+)$-turạnose were purchased from SERVA, Heidelberg, Germany, Test-Combination Gluco-quant ${ }^{\circledR}$ from Boehringer, Mannheim, Germany. Sephadex G-100 (particle size 40-120 $\mu \mathrm{m}$ ) was obtained from Pharmacia, Uppsala, Sweden. All other reagents were p.a. substances from Merck, Darmstadt, Germany.

\section{Preparation of human kidney homogenate}

Human kidneys were obtained by autopsy (no primary renal diseases were apparent), cut into fine slices, kept in ice-cold sodium chloride solution $(150 \mathrm{mmol} / \mathrm{l})$ containing EDTA $(1 \mathrm{mmol} / \mathrm{l})$. and homogenized by 5 strokes at $700 \mathrm{~min}^{-1}$ in a chilled Potter-Elvehjem homogeniser with a Teflon pestle. The ratio of sodium chloride solution to tissue was $1: 1(\mathrm{v} / \mathrm{w})$. After sieving, the homogenate was diluted to a final ratio $4: 1(\mathrm{v} / \mathrm{v})$, stirred with Triton X$100(1 \mathrm{~g} / \mathrm{l})$ for $30 \mathrm{~min}$, then centrifuged at $105000 \mathrm{~g}$ for $60 \mathrm{~min}$ at $4^{\circ} \mathrm{C}$ in an ultracentrifuge.

\section{Human urine}

Freshly voided urines from healthy subjects were collected in polyethylene bottles containing sodium azide (final concentration about $1 \mathrm{~g} / \mathrm{l}$ ) to prevent bacterial growth. Pooled urine samples were concentrated by ultrafiltration (YM 10 Diaflo membranes, Amicon, Witten, Germany) in the presence of bovine serum albumin (9).

\section{Gel filtration}

Supernatant from human kidneys $(5 \mathrm{ml})$ or concentrated human urine $(5 \mathrm{ml})$ was applied to a Sephadex G-100 column $(1.5 \times 67 \mathrm{~cm})$, and eluted at flow rates of $10 \mathrm{ml} / \mathrm{h}$, using the same sodium chloride solution as used for homogenisation (7). Protẹin was monitored continuously at $280 \mathrm{~nm}$ and fractions of $3 \mathrm{ml}$ were collected automatically (ISCO fraction collector supplied with an UA-5 absorbance monitor).

Each fraction was assayed for protein, with bovine serum albumin as standard (i0), and for $\alpha$-glucosidase activities. Fractions with the highest specific activity of neutral or acid $\alpha$-glucosidase were pooled and concentrated by ultrafiltration (9). After a second gel filtration, fractions were used for subsequent studies. The following specific activities were obtained for neutral $\alpha$-glucosidase $(7.5$ nkat $/ \mathrm{mg}$ from kidney, $1.5 \mathrm{nkat} / \mathrm{mg}$ from urine) and acid $\alpha$-glucosidase (2.2 nkat/mg from kidney, $19.5 \mathrm{nkat} / \mathrm{mg}$ from urine) respectively.

\section{Assay of neutral and acid $\alpha$-glucosidase}

\section{Principle of the 2-step methods}

The discontinuious àssays are 2-step methods based on the liberation of glucose via $\alpha$-glucosidase from maltose as substrate (step I) and the subsequent determination of glucose by hexokinase/glucose-6-phosphate dehydrogenase (11) in stẹp II (see scheme

Maltose $+\mathrm{H}_{2} \mathrm{O} \underset{(\mathrm{EC} 3.2 .1 .3 \text { or EC 3.2.1.20) }}{\longrightarrow} 2 D$-Glucose

$2 D$-Glucose +2 ATP $\frac{\text { Hexokinase }}{(\text { EC 2.7.1.1) }}$ 2D-Glucose-6- $P+2$ ADP
$2 D$-Gluccose-6- $P+2$ NADP $+\frac{\text { Glucose-6-P dehydrogenase }}{(E \bar{C} 1.1 .1 .49)}$
$2 D$-Gluconolactone-6- $P+2 \mathrm{NADPH}+2 \mathrm{H}^{+}$

Incubation (step I)

According to the observed properties of neutral and acid $\alpha$-glucosidase presented in "Results and Discussion", the following incubation conditions were optimal for the selective liberation of glucose from maltose by the respective enzymes (tab. 1 and 2). $0.25 \mathrm{ml}$ of each individual sample was mixed with $0.25 \mathrm{ml}$ of the appropriate substrate-buffer-solution and incubated for $60 \mathrm{~min}$ at $37^{\circ} \mathrm{C}$ in a reagent tube (Eppendorf Micro test tübes, Eppendorf Gerätebau, Netheler \& Hinz, Hamburg, Germany). In the same way a blank of each individual sample $(0.25 \mathrm{ml}$ sample and

Tab. 1. Neutral $\alpha$-glucosidase (EC 3.2.1.20).

Final concentrations of substrate-buffer-solution in the incubation medium

Citrate-phosphate buffer, pH 6.8
Citrate

Phosphate

Maltose

$20 \mathrm{mmol} / \mathrm{h}$

Turanose

$25 \mathrm{mmol} / \mathrm{A}$

Tab. 2. Acid $\alpha$-ğlucosidase (EC 3.2.1.3).

Final concentrations of substrate-buffer-solution in the incubation medium

Citrate-phoospuhate buffer, pH 3.8
Citrate

Phosphate

$75 \mathrm{mmol} / \mathrm{h}$

Maltose

$83 \mathrm{mmol} / \mathrm{h}$

Potassium chloride

$50 \mathrm{mmol} /$

$2 \mathrm{~mol} / \mathrm{h}$ 
$0.25 \mathrm{ml}$ citrate-phosphate buffer) and a blank of the substratebuffer-solution $(0.25 \mathrm{ml}$ substrate-buffer-solution and $0.25 \mathrm{ml}$ citrate-phosphate buffer) was prepared to determine free glucose. The reactions were stopped in the reagent tubes by heat denaturation ( $5 \mathrm{~min}$ in a boiling water bath). After subsequent centrifugation three $0.1 \mathrm{ml}$ aliquots of the incubation medium, (except single $0.1 \mathrm{ml}$ aliquots in the case of blank samples) were used for glucose determination.

The samples originating from human kidney or urine did not change the $\mathrm{pH}$-values of the incubation media for the determination of neutral or acid $\alpha$-glucosidase.

Substrate-buffer-solutions were stored frozen in small aliquots. Maltose and turanose contained less than 0.3 and $0.5 \%$ free glucose, respectively.

Glucose determination (step II) according to Test-Combination Gluco-quant ${ }^{\circledR}$

Solution $\mathrm{I}(2 \mathrm{ml})$ was added to $0.1 \mathrm{ml}$ aliquots of the incubation medium. After measuring the absorbance at $334 \mathrm{~nm}$ at $25^{\circ} \mathrm{C}$ (Photometer, PMQ III, Zeiss, Oberkochen, Germany or Eppendorf Digitalphotometer), $0.02 \mathrm{ml}$ solution II was added; after 15 min, absorbance $\mathbf{A}_{2}$ was measured (tab. 3). Final concentrations in the glucose assay are given for solution I and II (tab. 4).

The following substances as used in the incubation medium did not interfere with the glucose determination: buffer, maltose, turanose, potassium chloride, sodium chloride and bovine serum albumin. The transfer of $0.1 \mathrm{ml}$ aliquots of the incubation medium for the determination of the neutral or acid $\alpha$-glucosidase had no effect on the $\mathrm{pH}$-value of 7.6 in solution I or in the glucose determination.

Tab. 3. Procedure of the glucose determination

$\begin{array}{lll}\text { Sample } & \begin{array}{l}\text { Blank of } \\ \text { the sample }\end{array} & \begin{array}{l}\text { Blank of the } \\ \text { substrate- } \\ \text { buffer-solution }\end{array}\end{array}$

\begin{tabular}{llllll}
\hline $\begin{array}{l}\text { Aliquots of the } \\
\text { incubation medium }\end{array}$ & $0.1 \mathrm{ml}$ & $0.1 \mathrm{ml}$ & $0.1 \mathrm{ml}$ \\
$\begin{array}{l}\text { Solution .I } \\
\mathrm{A}_{1}\end{array}$ & $2.0 \mathrm{ml}$ & $2.0 \mathrm{ml}$ & $2.0 \mathrm{ml}$ \\
Solution II & $0.02 \mathrm{ml}$ & $0.02 \mathrm{ml}$ & $0.02 \mathrm{ml}$
\end{tabular}

$A_{2}$ after 15 min

$$
\begin{aligned}
\Delta A= & \left(\mathbf{A}_{2}-\mathbf{A}_{1}\right) \text { sample } \\
& -\left(\mathbf{A}_{2}-\mathbf{A}_{1}\right) \text { blank sample } \\
& -\left(\mathbf{A}_{2}-\mathbf{A}_{1}\right) \text { blank substrate } \mathbf{A}_{\text {buffer-solution }}
\end{aligned}
$$

Tạb. 4. Glucose determination acçording to Test=Cominbination Gluco-quant ${ }^{\star}$.

Final concentrations in the test

Solution I

Phosphate buffer

Magnesium sulfate

NADP $^{+}$

ATP

Solution II

Hexokinase

Glucose-6-phosphate dehydrogenase

\section{Calculation of $\alpha$-glucosidase activity}

Changes in NADPH absorbance $\triangle A$ (see tab. 3 ) were calculated and used to calculate $\alpha$-glucosidase activities expressed in nmoles maltose hydrolysed per second, per liter (nkat/l) according to the following equation.

$$
\begin{aligned}
\text { Catalytic activity concentration } & =\frac{1}{2} \times \frac{\Delta A}{\Delta t} \times \frac{V \times 2}{\varepsilon \times L \times v} \\
& =\frac{\Delta A}{h} \times 952.89[\text { nkat/l] }
\end{aligned}
$$

$\Delta \mathrm{A} / \Delta \mathrm{t}$ is the change in absorbance per incubation time; since 2 mol glucose are liberated per $1 \mathrm{~mol}$ maltose the absorbance must be divided by $2 ; \mathrm{V}$ is the reaction volume in the cuvette $(2.12 \mathrm{ml}), 2$ is the sample dilution factor in the incubation, $\varepsilon$ is the molar lineic absorbance $\left(618 \mathrm{~m}^{2} \times \mathrm{mol}^{-1}\right)$; $\mathrm{L}$ is the pathlength of the cuvette $(0.01 \mathrm{~m}), \mathrm{v}$ is the aliquot of incubation medium used $(0.1 \mathrm{ml})$.

\section{Results and Discussion}

\section{Selective properties of neutral $\alpha$-glucosi- dase}

We have confirmed that neutral $\alpha$-glucosidase from human kidney $(5,6)$ and human urine $(6)$ revealed similar broad $\mathrm{pH}$-curves with maximal activity at pH 6.8 (fig. 1). At pH 3.8 the residual enzyme activity was about $50 \%$, as also shown for the highly purified neutral $\alpha$-glucosidase (5). The enzyme activity was higher in citrate-phosphate buffer than in corresponding concentrations of citrate or phosphate

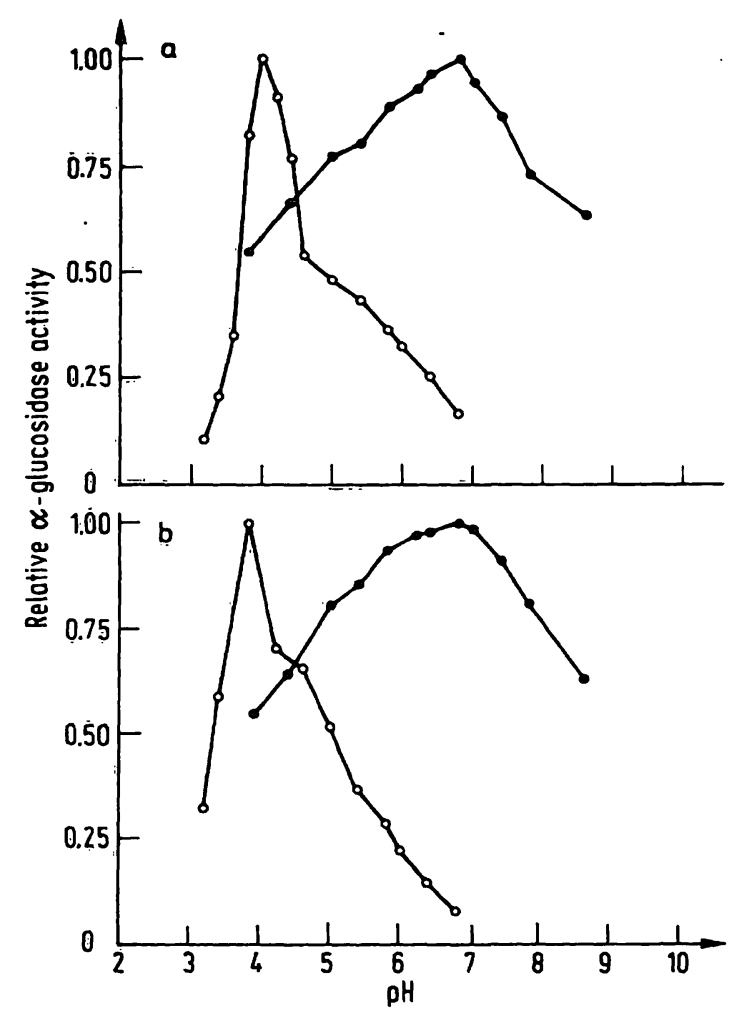

$15.7 \mu \mathrm{kat} / 1$ $28.3 \mu \mathrm{kat} / /$
Fig. 1. Activity of neutral (-@) and acid $\left(\mathrm{O}_{-}-\mathrm{O}\right) \alpha$-glucosidase as a function of $\mathrm{pH}$. Both enzymes were isolated from a) human kidney and b) human urine. 
alone. The molarity of the buffers had only small effects on enzyme activity. In citrate-phosphate buffer (pH 6.8) the neutral $\alpha$-glucosidase activity was highest at a phosphate concentration of $77 \mathrm{mmol} / \mathrm{l}$ (fig. 2).

Maximal activity of neutral $\alpha$-glucosidase from urine was reached at maltose concentrations between 10 and $20 \mathrm{mmol} / \mathrm{l}$ (fig. 3), while higher concentrations led to a slight substrate inhibition. $K_{\mathrm{m}}$-values were determined by Michaelis-Menten, Lineweaver-Burk and Hanes plots; the mean value was $0.53 \mathrm{mmol} / \mathrm{h}$, which is similar to values already reported for human urine (2) and human kidney (5). The activity of neutral $\alpha$-glucosidase was inhibited competitively by turanose with respect to maltose as substrate (fig. 3).

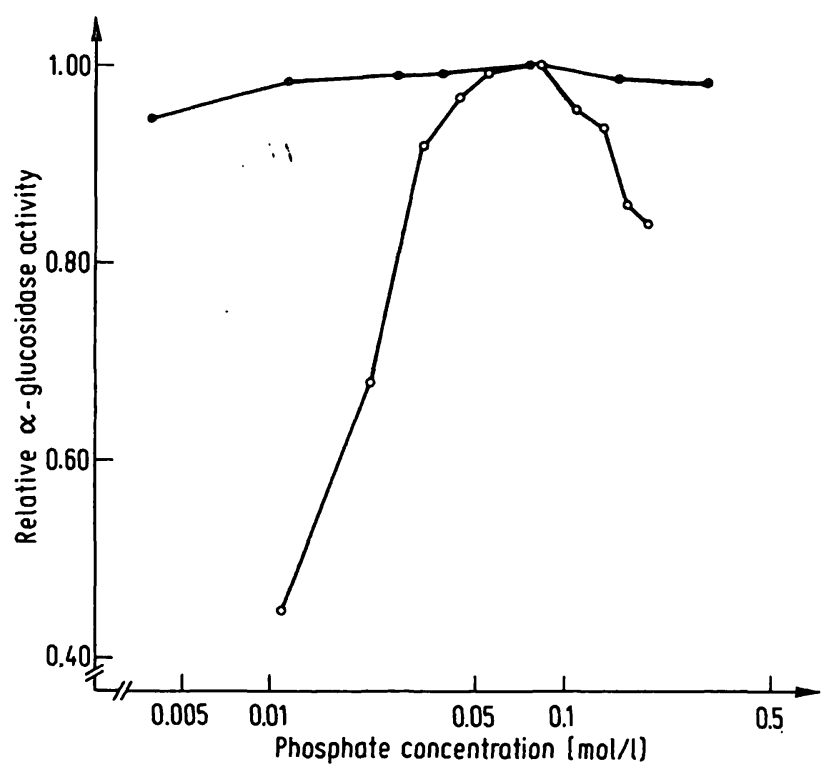

Fig. 2. Activity of neutral $(\mathbf{O}-\mathbf{O})$ and acid $(\mathrm{O}-\mathrm{O}) \alpha$-glucosidase (human urine) as a function of citrate-phosphate buffer $(\mathrm{pH}=6.8$ or $\mathrm{pH}=3.8$, respectively) concentration (plotted against phosphate concentration).

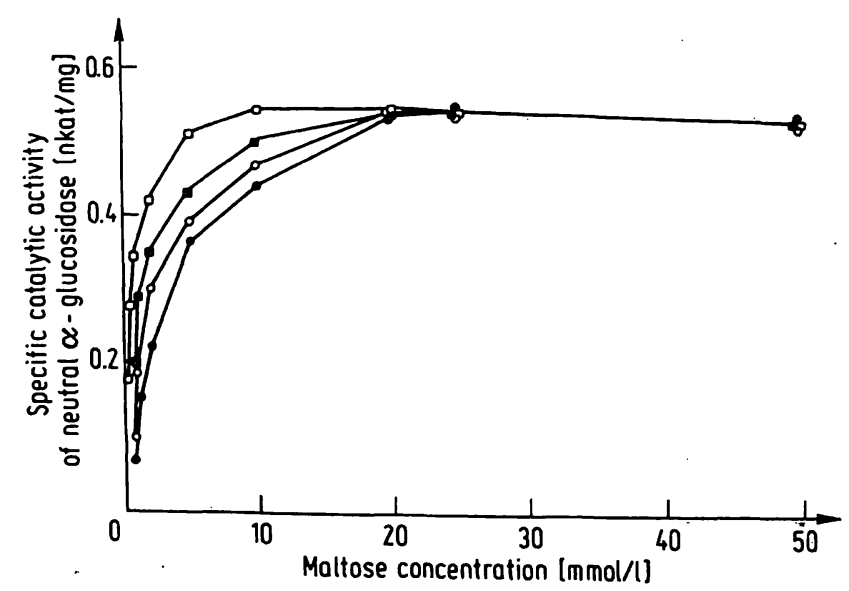

Fig. 3. Specific catalytic activity of neutral $\alpha$-glucosidase (human urine) as a function of maltose concentration in the absence and presence of turanose $(\square-\square$ without turanose, $\square 5 \mathrm{mmol} / \mathrm{l}, \mathrm{O} \longrightarrow 20 \mathrm{mmol} / \mathrm{C}, \longrightarrow 25$ $\mathrm{mmol} / \mathrm{l}$ turanose).
Calculations based on the Lineweaver-Burk and Dixon plots revealed a mean $K_{1}$-value of $5.9 \mathrm{mmol} / \mathrm{l}$. The same type of inhibition with a similar $K_{\mathrm{I}}$-value was found for neutral $\alpha$-glucosidase from human kidney (5). At higher ratios of maltose to turanose, no significant inhibitory effect on neutral $\alpha$-glucosidase activity was observed (fig. 3).

The activity of neutral $\alpha$-glucosidase from human urine decreased at $\mathrm{pH} 6.8$ and 3.8 with increasing potassium chloride concentration in the incubation medium (fig. 4). Compared with the optimal conditions for the assay of neutral $\alpha$-glucosidase, the activity of the enzyme is reduced to $2.6 \%$ at pH 3.8 in the presence of $2 \mathrm{~mol} / 1$ potassium chloride. Therefore under our assay conditions for acid $\alpha$-glucosidase, the residual activity of neutral $\alpha$-glucosidase is less than $3 \%$. Higher potassium chloride concentrations than those used in our assay led to a stronger inactivation of neutral $\alpha$-glucosidase (fig. 4). The inhibitory effect of potassium chloride on neutral $\alpha$ glucosidase is due to the potassium ions, and not to the chloride ions or to the increased ionic strength $(5,6)$.

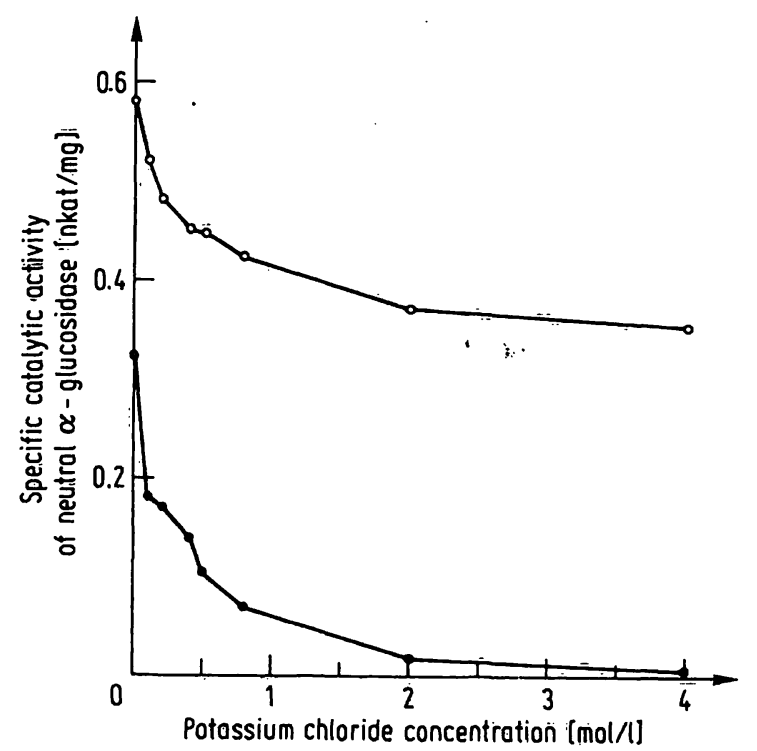

Fig. 4. Inhibition of neutral $\alpha$-glucosidase (human urine) ạs a function of potassium chloride concentration measured at $\mathrm{pH} 6.8(\mathrm{O}-\mathrm{O})$ and $3.8(0-\mathrm{O})$.

\section{Selective properties of acid $\alpha$-glucosidase}

As previously found, acid $\alpha$-glucosidase from human kidney $(6,7)$ and human urine $(6)$ show similarly shaped $\mathrm{pH}$ curves, with maximal activity at $\mathrm{pH} 3.8$ and 4.0 , respectively (fig. 1). At $\mathrm{pH} 6.8$ the residual enzyme activity was about 15 to $20 \%$, which is in agreement with earlier studies $(6,7)$. The enzyme activity was higher in citrate-phosphate buffer than in other buffer solutions such as citrate, acetate, suc- 
cinic acid and dimethylglutarate at corresponding concentrations. The molarity of the buffers had a strong effect on enzyme activity. Maximal activities of acid $\alpha$-glucosidase were found in citrate-phosphate buffer at a phosphate concentration of 83 $\mathrm{mmol} / \mathrm{l}$ (fig. 2).

Potassium chloride at a concentration of $2 \mathrm{~mol} / \mathrm{l}$ in the incubation medium stimulated the acid $\alpha$-glucosidase 1.5 fold (fig. 5). Maximal activity of the stimulated enzyme (in contrast to that of the unstimulated enzyme) was reached at maltose concentrations of $20 \mathrm{mmol} / /$, while substrate concentrations higher than $50 \mathrm{mmol} / \mathrm{l}$ led to a slight substrate inhibition. Using data from figure $5, K_{\mathrm{m}}$-values for acid $\alpha$-glucosidase were determined by Michaelis-Menten, Lineweaver-Burk and Hanes plots; the mean value was $11.5 \mathrm{mmol} / \mathrm{l}$ for the unstimulated enzyme and 2.8 $\mathrm{mmol} / \mathrm{l}$ for the potassium ion-stimulated enzyme. Similar $K_{\mathrm{m}}$-values were found for the unstimulated acid $\alpha$-glucosidase from human urine (2) and human kidney (12). Potassium ions caused an increased affinity of acid $\alpha$-glucosidase for maltose, as well as an increased rate of maltose hydrolysis (fig. 5).

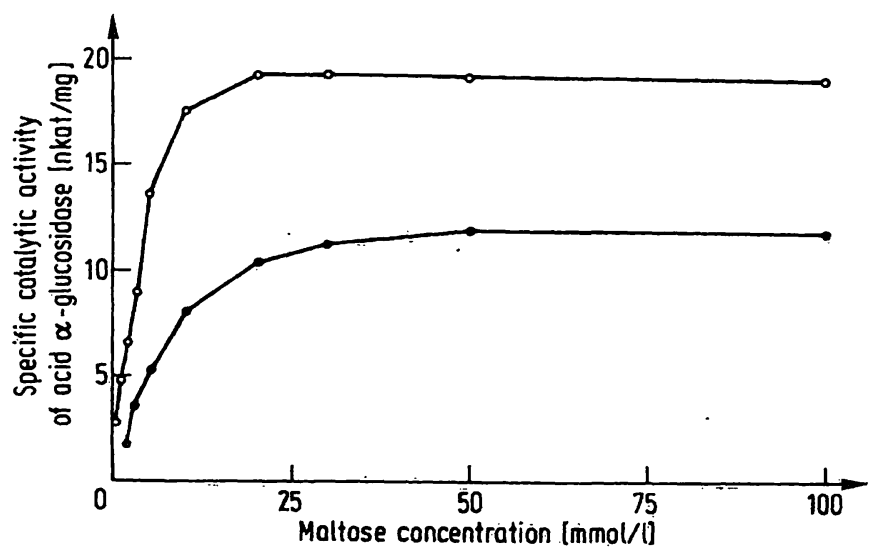

Fig. 5. Specific catalytic activity of acid $\alpha$-glucosidase (human urine) as a function of maltose concentration in the presence $(\mathrm{O}-\mathrm{O}, 2 \mathrm{~mol} / \mathrm{l})$ and absence $\left({ }_{-}\right)$) of potassium chloride.

The stimulatory effect of potasssium chloride is caused by potassium ions and not by chloride ions or by the increased ionic strength $(6,8)$. Since potassium chloride inhibits neutral $\alpha$-glucosidase and stimulates acid $\alpha$-glucosidase, it has been used previously to enhance the selectivity of $\alpha$-glucosidase determinations (6).

Turanose preferentially inhibits acid $\alpha$-glucosidase $(7,13)$. Investigations of the turanose effect on acid $\alpha$-glucosidase showed a strong dose-dependent inhibition of acid $\alpha$-glucosidase by turanose at concentrations up to $50 \mathrm{mmol} / \mathrm{l}$ (fig. 6). Using these data

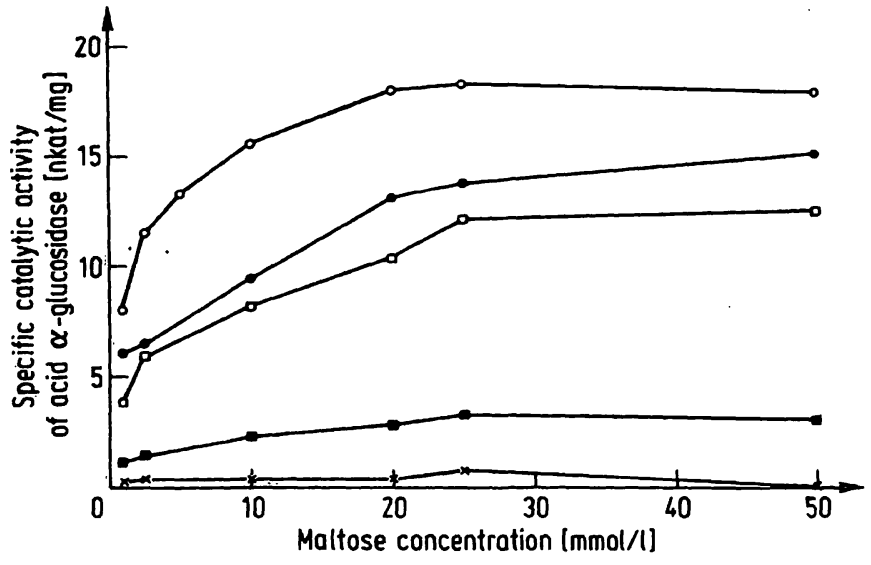

Fig. 6. Specific catalytic activity of acid $\alpha$-glucosidase (human urine) as a function of maltose concentration in the absence and presence of turanose. $(\mathrm{O}-\mathrm{O}$ without turanose, $\longrightarrow 5 \mathrm{mmol} / \mathrm{l}, \square \longrightarrow \square 10 \mathrm{mmol} / \mathrm{l}, \square-\square 25$ $\mathrm{mmol} / \mathrm{h}, \times \longrightarrow 50 \mathrm{mmol} / \mathrm{l}$ turanose).

and applying Lineweaver-Burk and Dixon plots, a mixed type but mostly noncompetitive inhibition was found, with a mean $K_{\mathrm{I}}$-value of $3.0 \mathrm{mmol} / \mathrm{l}$. A mixed type inhibition was also observed for the inhibition of acid $\alpha$-glucosidase from rat liver by turanose (14). Compared with optimal assay conditions, the activity of acid $\alpha$-glucosidase is reduced to $22 \%$ by increasing the $\mathrm{pH}$ of the incubation medium from 3.8 to 6.8 in the absence of turanose. The presence of 25 $\mathrm{mmol} / \mathrm{l}$ turanose in addition to the $\mathrm{pH}$-increase reduced the activity of acid $\alpha$-glucosidase to $2.7 \%$. Therefore under our assay conditions for neutral $\alpha$ glucosidase, the residual activity of acid $\alpha$-glucosidase amounts to less than $3 \%$. The highest turanose concentration used $(50 \mathrm{mmol} / \mathrm{l})$ led to a complete inhibition of acid $\alpha$-glucosidase at pH 6.8 and 3.8.

Selectivity of the assay for neutral $\alpha$-glucosidase

On the basis of the observed properties of neutral $\alpha$ glucosidase (after separation and partial purification by gel filtration on Sephadex G 100), the following conditions were chosen for the assay: an optimal pHvalue of 6.8 , the optimal citrate-phosphate buffer at the optimal phosphate concentration of $77 \mathrm{mmol} / \mathrm{h}$ and an optimal substrate concentration of $20 \mathrm{mmol} / \mathrm{h}$ maltose, with one hour incubation at $37^{\circ} \mathrm{C}$. The main advantage of this 2-step assay is the selectivity of the determination of neutral $\alpha$-glucosidase achieved by the addition of $25 \mathrm{mmol} / \mathrm{l}$ turanose to the incubation medium. Under these assay conditions turanose has no effect on the activity of neutral $\alpha$-glucosidase, whereas acid $\alpha$-glucosidase is inhibited by turanose to a residual activity of less than $3 \%$ (compared with the activity measured in an optimal determination of acid $\alpha$-glucosidase). 
Glucose concentrations up to $5 \mathrm{mmol} / \mathrm{h}$ in the samples did not disturb the determination of neutral $\alpha$ glucosidase. The activity of neutral $\alpha$-glucosidase is inhibited by tris and by erythritol $(5,12)$.

\section{Selectivity of the assay for acid $\alpha$-glucosi-} dase

On the basis of the observed properties of acid $\alpha-$ glucosidase (after separation and partial purification by gel filtration on Sephadex G 100), the following conditions were chosen for the assay: an optimal $\mathrm{pH}-$ value of 3.8 , the optimal citrate-phosphate buffer at the optimal phosphate concentration of $83 \mathrm{mmol} / \mathrm{l}$ and an optimal substrate concentration of $50 \mathrm{mmol} / \mathrm{l}$ maltose. The main advantage of this 2-step assay is the selectivity of the determination of acid $\alpha$-glucosidase achieved by the addition of $2 \mathrm{~mol} / \mathrm{l}$ potassium chloride to the incubation medium. Under these conditions, potassium ions stimulate the activity of acid $\alpha$-glucosidase, whereas neutral $\alpha$-glucosidase is inhibited by potassium ions to a residual activity of less than $3 \%$ (compared with the activity measured under optimal conditions). The high buffer capacity of the incubation step is necessary to maintain the $\mathrm{pH}$-value at 3.8. This is of particular importance since an increase of the $\mathrm{pH}$-value would lead to an increased residual activity of neutral $\alpha$-glucosidase even in the presence of potassium ions. Potassium chloride has been used previously to enhance the selectivity. of $\alpha$-glucosidase determinations (6), but in this fluorimetric assay, which utilized synthetic 4methylumbelliferyl-pyranoside as substrate, potassium chloride at a concentration of $4 \mathrm{~mol} / \mathrm{l}$ was much less effective as an inhibitor of neutral $\alpha$-glucosidase (6).

Glucose concentrations up to $5 \mathrm{mmol} / \mathrm{l}$ in the samples did not disturb the determination of acid $\alpha$-glucosidase. The activity of acid $\alpha$-glucosidase is inhibited by tris and by erythritol (12).

\section{References}

1. Salafsky, I. S. \& Nadler, H. L. (1973) J. Lab.. Clin. Med. 81, 450-454.

2. Franzini, C. \& Bonini, P. A. (1967) Clin. Chim. Acta 17, 505-510.

3. Dahlqvist, A. (1974) In: Methoden der enzymatischen Analyse (Bergmeyer, H. U., ed.) 3. Aufl., Bd. 1, 950-957, Verlag Chemie, Weinheim/Bergstr.

4. Brown, B. I. \& Brown, D. H. (1965) Biochim. Biophys. Acta $110,124-133$.

5. de Burlet, G. \& Sudaka, P. (1977) Biochimie 59, 7-14.

6. Soyama, K., Ono, E., Shimada, N., Tanaka, K. \& Kusunoki; T. (1977) Clin. Chim. Acta 77, 61-67.
Precision of the assay of neutral and acid $\alpha$ glucosidase

For both the assay of neutral and acid $\alpha$-glucosidase a linear relation was found between incubation time and maltose hydrolysis for more than, 1 hour, if fixed activities of $\alpha$-glucosidase were used. In addition linearity was also observed for the relation between substrate hydrolysis and activities of $\alpha$-glucosidase in the range from 5 to 800 nkat/l. To check the selectivity of the assays, neutral and acid $\alpha$-glucosidase were mixed in a ratio of $1: 3$ and $1: 5$ according to their activities. $98.0 \pm 0.6 \%$ of the activity of neutral $\alpha$-glucosidase and $97.7 \pm 0.3 \%$ of the activity of acid $\alpha$-glucosidase was recovered. In addition, as expected from the properties of neutral and acid $\alpha$-glucosidase found in this study, neutral $\alpha$-glucosidase revealed less than $3 \%$ activity in the assay of acid $\alpha$ glucosidase and inversely acid $\alpha$-glucosidase revealed less than $3 \%$ activity in the assay of neutral $\alpha$ glucosidase. The within-run precision of the determination of the activity of neutral as well as acid $\alpha$ glucosidase was determined and the coefficient of variation wâs calculated for neutral $\alpha$-glucosidase to be $3.3 \%(n=50 ; 78.35 \pm 2.58[$ nkat $/ 1])$ and for acid $\alpha$-glucosidase to be $3.5 \%(n=30 ; 140 \pm 4.9$ [nkat/l]). The day-to-day precision was studied for 10 days by repeated analysis of aliquots of the same samples. The coefficient of variation for neutral $\alpha$ glucosidase was $4.6 \%$ and for acid $\alpha=$ glucosidase $4.9 \%$.

\section{Acknowledgements}

A part of these studies was done in partial fulfilment of the requirements for the M.D. degree by G. Kochmann. The excellent technical assistance of Mrs. K. Berndt and Mrs. B. Lutteroth is appreciated. Preliminary notes on this work have appeared in $a b-$ stract form $(15-17)$. These studies were supported by the Deutsche Forschungsgemeinschaft $\mathrm{Ba} 271 / 6$.
7. Auricchio, F. \& Bruni, C. B. (1967) Biochem. J. 105, 35-38.

8. Jeffrey, P. L., Brown, D. H. \& Brown, B. I. (1970) Biochemistry $9,1403-1415$

9. Pape, W., Kochmann, R., Kochmann, G., Blank, M: \& Baumann, K. (1983) J. Clin. Chem. Clin. Biochem. 21, 511517.

10. Schacterle, G. R. \& Pollack, R. L. (1973) Anal. Biochem. 5I, 654-655.

11. Bergmeyer, H. U., Bernt, E.,.Schmidt, F. \& Stork, H. (1974) In: Methoden der enzymatischen Analyse (Bergmeyer, H. U., ed.) 3. Aufl., Bd. 2, 1241-1246, Verlag Chemie; Weinheim/Bergstr. 
12. Auricchio, F., Bruni, C. B, Sica, V. (1968) Biochem. J. $108,161-167$

13. Lejeune, N., Thines-Sempoux, D. \& Hers, H. G. (1963) Biochem. J. $86,16-21$.

14. Jeffrey, P. L., Brown, D. H. \& Brown, B. I. (1970) Biachem= istry $9,1416-1422$.
15. Kochmann, G., Kochmann, R., Pape, W. \& Baumann, K. (1980) J. Clin. Chem. Clin. Biochem. 18, 685 (abstract)

16. Kochmann, G., Kochmann, R., Willenbockel, Ch. \& Baumann, K. (1980) Kidney Int. 17, 409 (abstract).

17. Willenbockel, Ch., Franzen-Sieveking, M. \& Baumann, K. (1980) Kịdney Int. 17, 418 (abstract).

Gabriela Kochmann

Abteilung für Zellphysiologie

Physiologisches Institut der Universität Hamburg

Grindelallee 117

D-2000 Hamburg 13 


$$
\text { 。 }
$$

